\title{
Optimalisasi Layanan Informasi Dan Administrasi Sanggar Kegiatan Belajar Ponorogo Kepada Masyarakat
}

\author{
Khoiru Nurfitri*, Ismail Abdurrozzaq Zulkarnain, Nurwanto \\ Universitas Muhammadiyah Ponorogo \\ Jl. Budi Utomo No. 10 Ponorogo \\ Telp.: (0352) 481124, 487662, Fax : (0352) 461796 \\ humas@umpo.ac.id
}

\begin{abstract}
The management of data at UPT Sanggar Kegiatan Belajar Ponorogo is still done manually. Given the current era of globalization, many companies/agencies have used computerized systems to manage data in order to simplify and speed up work. Based on the description above, we carry out community service activities in the form of developing and applying a computerized data management system in the Ponorogo'SKB. The system that we built is an information and administration system. Based on a computerized system capable of processing data quickly and accurately as well as being able to store and display transaction data related to administration. The method we use in this activity is to provide a computerized system and directly conduct training as well as assistance in operating the system. We hope that by developing this administrative information system the Ponorogo community can more easily access information about the SKB Ponorogo and make it easier to manage the administration of the SKB better and faster. Until now, our activities have reached the stage of training in the operation of the information system for all admins in SKB Ponorogo.
\end{abstract}

Keywords: Sanggar Kegiatan Belajar, Information System, Administration System, Ponorogo

\begin{abstract}
Abstrak
Managemen data UPT Sanggar Kegiatan Belajar Ponorogo masih dilakukan secara manual. Mengingat pada era globalisasi saat ini telah banyak perusahaan/instansi yang menggunakan sistem terkomputerisasi untuk mengelola data guna mempermudah dan mempercepat pekerjaan. Berdasarkan uraian di atas maka kami melaksanakan kegiatan pengabdian berupa mengembangkan dan mengaplikasikan sebuah sistem pengelolaan data terkomputerisasi di SKB Ponorogo. Adapun sistem yang kami bangun adalah sebuah sistem informasi dan administrasi. Berdasarkan sistem terkomputerisasi mampu memproses data secara cepat dan akurat serta mampu menyimpan dan menampilkan data transaksi yang berkaitan dengan administrasi. Metode yang kami gunakan dalam kegiaan ini adalah menyediakan sistem terkomputerisasi dan secara langsung melakukan pelatihan juga pendampingan dalam pengoperasian sistem tersebut. Harapan kami dengan dikembangkannya sistem informasi administrasi ini masyarakat ponorogo dapat lebih mudah dalam mengakses informasi tentang SKB Ponorogo dan mempermudah pengelolaan administrasi SKB dengan lebih baik dan lebih cepat. Sampai pada saat ini kegiatan kami telah sampai pada tahap pelatihan pengoperasian sistem informasi bagi seluruh admin yang ada di SKB Ponorogo.Abstrak ditulis dengan huruf miring dalam bahasa Indonesia dan bahasa Inggris dengan maksimal 250 kata. Abstrak merupakan ringkasan semua kandungan makalah, termasuk rumusan masalah, tujuan penelitian, metodologi, hasil dan pembahasan, serta kesimpulan.
\end{abstract}

Kata kunci: Sanggar Kegiatan Belajar, Sistem Informasi, Sistem Administrasi, Ponorogo. 


\section{PENDAHULUAN}

Sanggar Kegiatan Belajar (SKB) merupakan salah satu lembaga pemerintah yang menyelenggarakan pendidikan non formal dan informal. SKB Ponorogo beralamatkan di Jl. Soekarno Hatta No.78, Kelurahan Bangunsari, Kec. Ponorogo. SKB Ponorogo memiliki beberapa program penyelenggarakan pendidikan diantaranya yaitu tutor keaksaraan, PAUD, kursus Komputer, Kursus Tata Busana, dll. Berbicara mengenai akses informasi dan pelayanan administrasi yang ada di SKB tenyata masih manual. Mengingat dalam kondisi persaingan yang cukup ketat dan penuh tantangan pada era globalisasi ini, suatu lembaga pendidikan dituntut untuk bisa memberikan pelayanan yang sebaik-baiknya kapada peserta didik. Kualitas pelayanan ini menjadi salah satu indikator dari keberhasilan pelayanan. Upaya untuk memperbaiki kualitas pelayanan sudah seharusnya dilakukan dengan mengadopsi sistem yang terkomputerisasi. Untuk itu demi kenyamanan dan kelancaran proses administrasi SKB Ponorogo, maka sistem informasi administrasi perlu dirancang menjadi sistem informasi administrasi yang mengikuti perkembangan teknologi bukan sistem informasi administrasi manual lagi. Oleh sebab itu berdasarkan latar belakang diatas, kami peneliti ingin memberikan solusi dengan mengembangkan dan mengaplikasikan suatu alur kerja sistem administrasi yang berdasarkan sistem terkomputerisasi yang mampu memproses data secara cepat dan akurat serta mampu menyimpan dan menampilkan data transaksi yang berkaitan dengan administrasi. Harapan kami dengan dikembangkannya system informasi administrasi ini masyarakat ponorogo dapat lebih mudah dalam mengakses informasi tentang SKB Ponorogo dan mempermudah pengelolaan administrasi SKB dengan lebih baik dan lebih cepat.

\section{METODOLOGI PENELITIAN}

Tahap-tahap yang dilakukan dalam Penelitian ini adalah:

a) Analisis Masalah

b) Tahap ini merupakan sebuah proses untuk mengidentifikasi masalah yang ada di Sanggar Kegiatan Belahar (SKB) Ponorogo. Identifikasi dilakukan dengan cara wawancara langsung ke Kelapa SKB yakni Bapak Arif Pudianto S.H. Hasil identifikasi masalah yaitu bahwa SKB Ponorogo saat ini masih menggunakan cara manual dalam pengelolaan data terutama cara melakukan promosi kepada masyarakat dan kesulitan calon peserta didik yang akan mendaftar ke SKB. Pada tahapan ini pengabdi mengusulkan sebuah solusi yaitu membuatkan sistem informasi untuk promosi dan pendaftaran secara online berbasis web.

c) Perancangan

d) Pada tahan ini peneliti melakukan perancangan untuk membuat dan pengkodingan sistem informasi yang telah diusulkan.

e) Pengujian Tahap ini digunakan untuk menguji sistem yang telah dibangun dan 
mengunggah sistem agar sistem menjadi online. Dalam hal ini peneliti mengonlinekan website Sanggar Kegiatan Belajar dengan domain skbponorogo.com.

f) Implementasi

Pada tahap implementasi peneliti melakukan pelatihan serta pendampingan kepada Admin sistem. Adapun admin sistem ini diambilkan dari pegawai dari masing-masing program yang ada di SKB Ponorogo. Sekaligus pada tahap ini website diberikan sepenuhnya kepada SKB Ponorogo tetapi jika pihak SKB masih memerlukan pelatihan/pendampingan terkait pengoperasian sistem kami siap membantu.

\section{HASIL DAN PEMBAHASAN}

Berikut adalah hasil pengembangan sistem informasi dan administrasi UPT Sanggar Kegiatan Ponorogo. Sistem ini digunakan sebagi media promosi dan pendaftaran online SKB Ponorogo. Sistem Informasi ini telah kami online-kan dengan domain skbponorogo.com. Tujuan dari dibangunnya sistem ini adalah untuk media promosi dan juga untuk mempermudah calon warga belajar ketika mendaftarkan diri di SKB Ponorogo. Calon warga berlajar dapat mengakses informasi dan mendaftarkan diri dari manapun dan kapanpun tidak perlu datang ke SKB Ponorogo. Berikut adalah beberapa tampilan sistem informasi SKB Ponorogo:

\section{a) Tampilan Home}

Tampilan ini merupakan halaman utama ketika pengguna membuka website Sanggar Kegiatan Belajar Ponorogo. Pada Halaman Home ini akan ditampilkan beberapa menu yaitu meliputi:

1) Menu sosial media SKB yang meliputi Facebook, Twitter, Gmail, dan Instagram

2) Menu Home itu sendiri yang akan menampilkan gambar dengan model slide.

3) Menu Profil

4) Menu Visi dan Misi

5) Menu Dasar Hukum

6) Menu Kedudukan, Tugas, dan Fungsi

7) Menu Berita

8) Menu Pendaftaran

Berikut adalah tampilan halaman utama seperti yang ditunjukkan pada gambar berikut: 


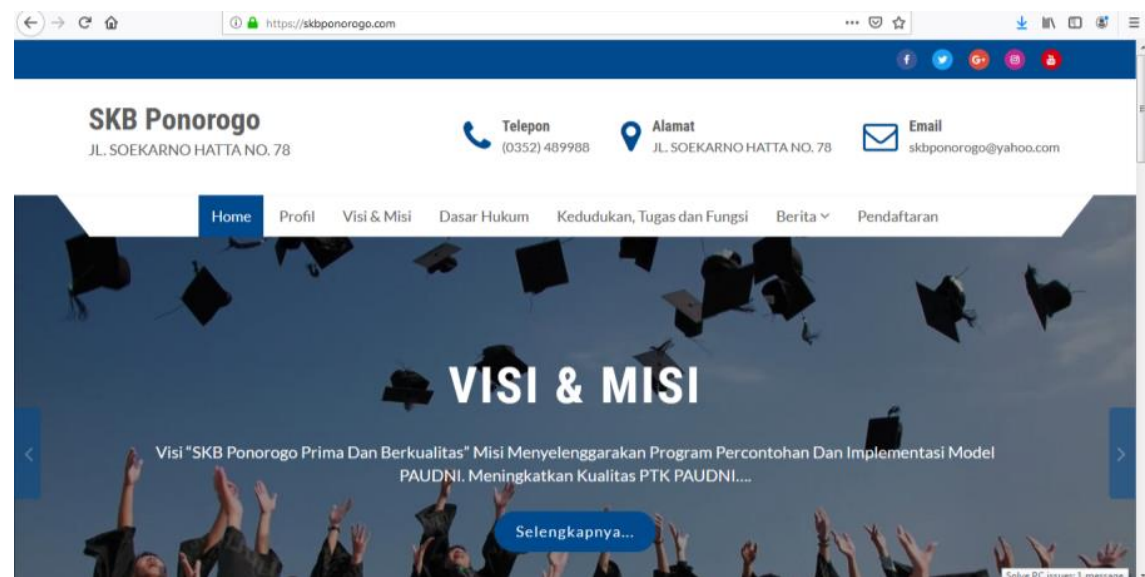

Gambar 1. Tampilan Halaman Utama

\section{b) Tampilan Profil}

Tampilan profil menampilkan tentang profil SKB Ponorogo. Adapun profil yang akan ditampilkan seperti lokasi, sejarah maupun perkembangan SKB.

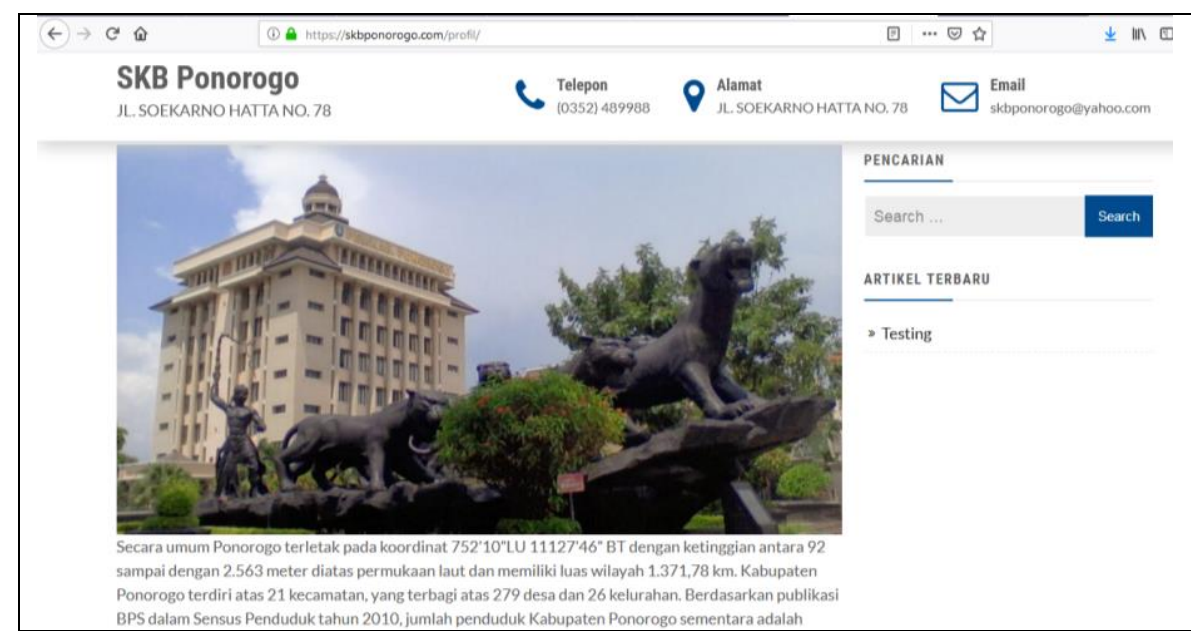

\section{Gambar 2. Tampilan Profil}

\section{c) Tampilan Pendaftaran}

Tampilan di atas ini merupakan tampilan pendaftaran. Para pendaftar online dapat mendaftarkan diri melalui tampilan ini dengan cara mengisi NIK dan Password.

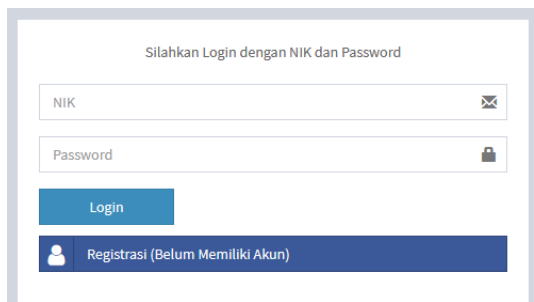

Gambar 3. Tampilan Pendaftaran 


\section{d) Tampilan Registrasi}

Bagi pendaftar online yang belum registrasi secara otomatis tidak bisa log-in pada tampilan pendaftran, maka diharapkan klik menu registrasi untuk melakukan registrasi, kemudian tampilan di atas ini akan tampil. Pengunjung diminta untuk mengisi data-data yang ada sampai dengan selesai.



Gambar 4. Tampilan Registrasi

\section{SIMPULAN}

Dengan adanya sistem informasi dan administrasi ini diharapkan masyarakat khususnya ponorogo dapat lebih mudah dalam mengakses informasi mengenai SKB Ponorogo serta memudahkan calon warga belajar dalam melakukan pendaftaran. Diharapkan juga dengan adanya pelatihan dan pendampingan pengoperasian sistem informasi kepada admin dapat diaplikasikan dengan baik, sehingga informasi yang tersaji di sistem bersifat update, serta dalam rangka memerikan pelayanan yang baik kepada masyarakat.

\section{DAFTAR PUSTAKA}

[1] Rahilah, dkk. 2013. Pengembangan dan Pembuatan Aplikasi. Semarang: Kompas Gramedia.

[2] Sutarman. 2007. Membangun Aplikasi Web dengan PHP \& MySQL, edisi ke-2. Yogyakarta: Graha Ilmu.

[3] Regi Witanto, \& Hanhan Hanafiah Solihin (2016). Perancangan Sistem Informasi Penerimaan Siswa Baru Berbasis Web (Studi Kasus : SMP Plus Babussalam Bandung), Jurnal Infotronik,Volume 1, No. 1, Desember 2016

[4] Apriani, \& Sandi Justitia Putra, (2018). Desain Sistem Informasi Penerimaan Siswa Baru Berbasis Web. Prosiding Sintesa. UNDHIRA Bali. 2 November 2018

[5] Nana Syaodih Sukmadinata, Pengembangan Kurikulum Teori dan Praktek, (Bandung: PT. Remaja Rosdakarya, April 2013), hal. 67 